\title{
Local Language As Cultural Cohesive Device In Janger Performing Art
}

\author{
Mochamad Ilham \\ Fakultas Ilmu Budaya, Unej \\ ilham.zb@gmail.com
}

Diterima 24 Januari 2018/Disetujui 8 Agustus 2018

\begin{abstract}
Janger performing art is still able to attract the public because of its ability to adopt various local languages in Banyuwangi. In addition to apply Javanese language, it also utilizes Using, Madurese, and Indonesia languages. Nevertheless, the actors of Janger cannot simply mix language. Appropriateness in applying and mixing languages is a prerequisite for being a successful actor. This article aims to analyze the ways in which actors adopt four languages in their performances. Therefore the relevant approach used is the perspective of orality. This approach leads to the answer that the local languages are the cultural cohesive device between Janger performing art and its audiences. Although using different languages, the three major ethnic groups in Banyuwangi, namely Using, Javanese, and Madurese can together become Janger supporters because symbolically all of them feel become the owner of Janger.
\end{abstract}

Key words: Janger performing art, cultural cohesive device, local languages.

\section{Introduction}

A number of traditional performing arts in East Java experienced remarkable setbacks in the last three decades. Those performing arts are abandoned their loyal viewers because they are considered irrelevant to be the media of entertainment. However, it does not happen in Janger Banyuwangi. This traditional theater is still accepted by the people seen from the existence and positive development of the theater nowadays. Of course there must be fundamental things that make Janger is still accepted by the people. It can be assumed that one of the things that make Janger still accepted by its audience is because this performing art succeeds in developing a unique orality strategy. Called unique because Janger audience is a multiethnic and multilingual society.

The Banyuwangi multilingual community encourages the art of Janger to choose multilingualism. Multilingual society is a society that uses more than two languages in communicating because the community is made up of two or more ethnicities, so that in everyday communication routine phenomenon occurs code switching and code mixing. The Banyuwangi community is a concrete example of multilingual society, and Janger is the best example of performing art that chooses multilingualism.

In Janger, the main language of the performance is Javanese language. However, because Janger, as a text, is in the context of a multiethnic and multilingual society, so for the sake of its survival it makes itself contextual. That is, Janger chooses to be multilingual so that the text in Janger performance can be considered as a social narrative. Narrative is a storehouse that holds oral-based community knowledge. The narrative, as Lyotard (2004) says, is the core of traditional knowledge. The narrative definition is always fluid. It is in spontaneous daily discourse. By their very nature, traditional oral societies do not require clarification of messages or information they receive. They do not weigh the information correctly or wrongly, but by "believe it or not." Reality has been mediated by narration. 
Since society and narrative are not distant, then the decision to believe or not to believe is to be taken immediately. How should people decide to believe or not to believe? For traditional societies, this is not something complicated. They will determine the validity of an information based on who delivered the information. This is also why the community does not need to do a deep watching to the Janger performance. They assume that Janger, as a cultural institution, has the credibility to express its cultural values, using Javanese as the main language and other languages-Using, Madurese, and Indonesian languages, as supporting languages.

Accommodations of these languages make Janger a trusted source of information. When Janger groups lifted Tawangalun to the stages, and placed him as a king who is "katarting budaya, hambeg martatama, wicaksana, berbudi bawa leksana, murah asih ing sasama" (understand the values, pursue the good, wise, virtuous, generous), the audience immediately agreed. When Minak Jinggo is ultimately portrayed as a wise protagonist, not an antagonist that disturbs the state's tranquility, the audience agrees. They believe that Janger artists have studied history thoroughly and earnestly.

This orality research in Banyuwangi does not only provide a theoretical challenge, but also methodological one. Therefore, this research requires field exploration by using the usual approach used in the field of folklore and anthropology studies. The conventional literary approach is not sufficient because the aspects and dimensions of orality are less appropriate if only explained by using textual analysis. Based on these considerations, this research uses textual approach, media theory, and ethnography. The textual approach is used to examine the conventions and variations of Janger performances because, as an oral literary product, the stories in the performances have elements that build the whole structure. In other words, the study of the convention of Janger focused on the text (the lore aspect). Meanwhile, the media approach will place the text as a social inscription of human action. The ethnographic approach is used to explore data about various aspects of socio-culture of Banyuwangi (its folk aspect) which is the context of Janger performing art.

\section{Research Methodology}

Hymes (1973) argues that language and folklore are cultural aspects that automatically become part of the factors of life of the supporting community. For Hymes (1973), language is the body of folklore. Therefore in discussing folklore, we cannot avoid talking about language. As part of the culture and as a vehicle for expressing culture, language contains the distinctive cultural values that society possesses. It happens because the language is used as a means to speak, think, express ideas, and to interact between community members and the environment.

In multilingual societies, such as the Banyuwangi community, where several regional languages and national language are used, it is possible to establish inter-language contacts. Therefore, in such situations of communication, the most common language phenomena are code switching and code mixing (Yuliana, 2015). Code switching is a transitional event from one code to another in a speech event, whereas the code mixing of a speech event in which the clauses or phrases used consist of mixed clauses and phrases and each of the clauses or phrases is no longer support each function (Mahootian, 2006). There is a significant difference between code switching and code mixing. Code switching occurs in every used language and it still has its own autonomy, done consciously, deliberately, and for some reasons. While code mixing is a primary code or basic code used to have functions and 
autonomy, while the other code involved in the use of the language is just an insertion with no function and autonomy as a code. Therefore, if in code switching we use two languages autonomously in turn, then in code mixing an element of another language is only inserted in the language that became the main code or basic code. When code switching is more related to situational aspects, code mixing is motivated by linguistic motivation and a desire to explain (Spolsky, 1998; Hymes, 1973).

Janger Banyuwangi can be called as a multicultural performing art as well as a multilingual one. Janger is called multicultural because this performing art adopts various cultural elements, namely Using, Java, and Bali. The multilingual title is derived by the fact that more than one languages are used in this performing art, although in general the language used in all parts of the story is Javanese, except for the comedy act. Some Janger groups even use the Indonesian language at the opening and closing performances. Such cultural situations, inevitably, cause the appearance of code switching and code mixing in Janger performances.

\section{Discussion}

Janger performance should be arranged in such a way as to meet the expectations of its multiethnic and multicultural audience. Since the whole story uses Javanese, the service portion for the audience in terms of language is left to the comedian. The average Janger comedian is able to joke in Javanese and Using language well and occasionally inserted the Indonesian language. Ganden, one of the famous comedians, is also proficient in jokes in Madurese. Therefore, if there is a performance in Madurese society, he is the most priority of comedian to be contracted. Ganden's ability to joke in Madurese language was obtained when in the 1980s he was often invited to join in several Ludruk performances, both in Banyuwangi and in Jember (Madurese people in East Java is one of the main supporters of Ludruk). While the Javanese and Using have been mastered by Ganden since childhood, as a colloquial.

\subsection{The Primary Language: Javanese}

Variety of Javanese language used in Janger performance is Mataraman Javanese, complete with undha-usuk (speech level; ngoko, krama madya, and krama inggil). The people of Banyuwangi call it boso kulonan (the language of west Javanese people). When a patih (prime minister) speaks to the king, he uses high Javanese (krama inggil), otherwise when he speaks to his subordinate soldiers, the language he uses is low Javanese (ngoko). Patih will use middle Javanese (krama madya) when he speaks with people who are considered equal status with him, for example by duke or commander. It would be hard to find a high level person talks in low Javanese to his equivalent colleagues, unless they are really familiar.

\section{Ibu}

Pakmu, anake dewe, Kebo Mancuet. Ya gene dheweke mangani sato kewan. Duh, Gusti... (Pada Kebo Mancuet) Ngger, kowe ki anake simbok. Kebo Mancuet. (Menangis) Lajeng, dosa menapa ingkang kula sandhang, Gusti.

\section{Bapak}

Iki bapakmu karo mbokmu, Ngger.

\section{Mother}

Dear, our son, Kebo Mancuet. Why did he eat animals? My God ... (To Kebo Mancuet) Son, you are my son. Kebo Mancuet. (Crying) Then, what sin I have to bear, God.

\section{Father}

This is your father and your 


\section{Kebo Mancuet \\ Aku njaluk ngapura, bapa, simbok ...}

\section{Bapak}

Iya-iya, tak ngapura pira-pira

kaluputanmu, Ngger.

(Kebo Mancuet, Babak 4)

\section{Bra Martunjung \\ Kakang Sindura.}

\section{Sindura}

Dawuh Dalem, Gusti Prabu.

\section{Bra Martunjung}

Yen kula ngraosaken wonten ing Bali Klungkung dereng saget rawuh wonten sasana agung. Malah Dimas Pancoran piyambakipun sampun pejah saking pangamukipun Kebo Mancuet. Ngantos kladeng jagat kula, Kakang Sindura. mother, son.

\section{Kebo Mancuet}

I'm sorry, mom and dad ...

\section{Father}

Yes, I forgive all your mistakes, son.

\section{Bra Martunjung \\ My brother, Sindura.}

\section{Sindura \\ Yes, my Lord.}

\author{
Bra Martunjung \\ I wonder why Bali Klungkung \\ cannot come to this important \\ meeting. In fact, Pancoran has \\ been killed by Kebo Mancuet. I \\ feel my world is dark, my brother \\ Sindura.
}

(Minak Jingga Winisudha, Babak 4)

The two quotes above show different situations. The first quote of dialogue goes on ngoko, while in the second quote all speakers use Javanese krama. The language levels used in the dialog on Janger may different due to the different situations, they can take place ngoko or krama. A dialogue in a family in an ordinary people's circle with the background of village life using low level of Javanese language. Verbal communication with this kind of setting is usually held by ngoko. When a dialogue takes place between important high-ranking people, for example between King Bra Martunjung and Patih Sindura, it uses high level of Javanese language or krama although the social strata of the speakers are different. This can happen because Patih Sindura is older and is respected by King Bra Martunjung even though his social status is lower.

The Javanese language is used on all occasions except in comedy act (dagelan), because in this part of the performance some Janger groups prefer their comedians deliver their jokes in Using language. Java language used is the standard language, complete with undha-usuk or level of speech. A certain character will talk krama or ngoko depending on who he is talking to. In practice, the language used by actors is not always based on precise grammar or diction. It may be due to an imperfect level of language ability, or because of the influence of the local dialect.

Originally, the language taught in elementary and junior high schools in Banyuwangi as a local content is the standard Javanese language of the regions of Surakarta and Yogyakarta, a dialect which is generally regarded as a standard Javanese language, but arguably barely has no practical or symbolic benefits in certain cultural areas such as Banyuwangi. Practically speaking, people who master the standard Javanese language are 
very few in Banyuwangi. Java language does exist, but mainly in various dialects of East Java (Arps, 2010).

For senior Janger artists, such as Jaswadi, Sugiyo, and Rohili, Janger performance is not Janger if it is not conducted in Javanese. Thus, based on Macedo (2003), it can be said that the use of Javanese in Janger performance is not a practice of hegemony, or a systematic attempt to make the community of Banyuwangi, especially Using people, as the subordinate of Java, but merely the cultural choice of society. However, although the main language used in Janger performance is Java language, the multilingual environment does not make this performing art strict in applying Javanese language as the main language of the performance. During the course of the performance the players are very likely to make the remarks in other languages, depending on the state of the audience at that time. In plantation areas, where the vast majority of viewers speak Madurese, the performers often insert their dialogue with Madurese language. For certain plays, such as Sungging Penatas, Panji Pulangjiwo, and Cakraningrat, the meeting scene (jejer) in the palace uses Madurese language.

\subsection{The Secondary Language: Using}

In Janger performance, Using language is often applied in the most interactive part between the actors and the audience, ie, the comedy act. The comedians, consisting of two to six people, are fully applying Using language, although in its development there is also mixed comedy act that mixes Javanese and Using languages, especially if the performance is held in a Javanese circumstance. It is intended that the communicative nature, namely the main condition of the success of a joke, can be fulfilled because both the comedian and the audience understand the languages well. By applying Using language, communication between comedians and viewers becomes intensive. The comedians threw jokes by using the idioms known by the audience, and the audience will respond them. The comedy act will fail if there is no interrelation between the comedians and the audience, and success is only possible if the language used is well understood by the comedians and the audience. Furthermore, they feel they are in the same cultural background. Using language is difficult to understand by Javanese people living outside Banyuwangi because Using language does not only have many vocabulary spoken differently from Javanese, but also because of the use of words that no longer exist in the current Javanese vocabulary. In addition, Using language also absorbs a lot of Malay vocabulary, and even English. However, Using language can be understood by Banyuwangi people who came from Javanese and other cultural background.

\section{Mentik}

Yo iku mau gending paran, Nyet?

Penyet

Tong-tong bolong.

Mentik

Oh, bolak-balik tong-tong bolong, ayo seketewau.

\section{Penyet}

Pas seketewau (Menjitak kepala Mentik).

Nggo gending arane hang enak.

\section{Mentik}

What song is that, Nyet?

\section{Penyet}

Tong-tong bolong.

\section{Mentik}

Oh, Tong-tong bolong again, fifty thousand, please.

\section{Penyet \\ Why fifty thousand (hit Mentik's head). A song must}




\section{Mentik}

Iku ya Gladak ngulon iku ya?

\section{Penyet}

Padhang Bulan.

(Senapati Majapahit, Babak 2) have a nice title.

\section{Mentik}

Is it Gladak to the west then?

\section{Penyet}

Padhang Bulan.

The above dialog is in Using language and it cannot be well understood without knowing the social context of society. "Gladag" is the name of the village where in the western part of it lies a famous prostitute localization called "Padhang Bulan." The tariff of hiring a prostitute is "seketewau" or Rp 50.000,-

The following quotation shows the change of language usage. Originally Penyet and Mentik, the comedians, conducted their dialogue in Using language, but when the comedy act was over, marked by the arrival of Damarwulan, they immediately changed their dialogue in Javanese language. This is a code changing that takes place in a Janger performance.

\section{Penyet}

Kene, kene ... Ya kudune awake dheweg iki kudu pinter ndeleng situasi. Ya nek ngadepi hang gedigu iku ... ya muga-muga aja sampek. Tapi upama ketotol, ketemu tenanan, ya carane kudu dirembug hang apik.

\section{Mentik}

Saiki gedigi, Lik ... awake dheweg iki ngemong Ndara ... hang ati-ati, hang sabar. (Damarwulan datang)

\section{Penyet}

Lha iya, awake deweg iki arane ...

\section{Mentik}

Abdi.

\section{Penyet}

Ho-oh. Jongos. Ngemong mulai ndesa sampek panggonan kene. Cita-citane kepingin urip enak, e tibane nong kene ya ... byek, dirasani ...

\section{Mentik}

Suwe-suwe sakaken nyawang Ndara iki ya.

\section{Penyet}

Takonana ... takonana ...

\section{Penyet}

Come here, please ... we should have to know the situation. If we are facing that problem ... well, hopefully we are fine. But if we mee him, we must talk it first.

\section{Mentik}

By the way, Lik ... we are nurturing Ndara ... we must cautious, must be patient.

\section{Penyet}

Yes, indeed ... we are ...

\section{Mentik}

Helper.

\section{Penyet}

Yes. Helper. Taking care from the village to this place. He wants to live well, but it here... well, it is discussed ...

\section{Mentik}

I'm so pity to see our lord.

\section{Penyet}

Ask him ... ask him ... 


\section{Mentik}

Napa ta ingkang dipenggalih, sawangane kok suntrut, mendhung.

\section{Penyet}

Enten napa ta Ndara ... mbok menawi kula saget sabiyantu kaliyan panjenengan.

\section{(Senapati Majapahit, Babak 2)}

\section{Mentik}

What do you think about, you look very sad.

\section{Penyet}

What's up, Sir ... maybe I can help you.

The apparent feature of applying Using language in the above dialog quotation is the dialect and the selection of the first person pronoun, isun, and the second person's pronoun, rika. Other Using vocabulary that look very different from the Javanese are hang (which), gedigu (like that), gedigi (like this). The quotation above shows that the language phenomenon that occurs in the comedy act not only code mixing, but also code switching.

Broadly speaking, the content of Using language (vocabulary, grammar, and phonology) has not changed much, but on the contrary its socio-cultural status has greatly changed in a political process that also involves the formation of regional identities in other fields, other than language (Arps, 2010). According to Rohili, group director of Janger Sritanjung Mardi Santoso, the previous regent of Banyuwangi, Syamsulhadi, once planned Janger show in Using language, but the artists refused it. Rohili himself, a senior Janger actor that speaks Using in his daily life, finds it difficult to speak Using in Janger performance because he used to have dialogues in Javanese. In addition, according to him, "Javanese is more suitable for Janger."

\subsection{The Other Language: Indonesian}

As previously mentioned, in addition to apply Javanese and Using, Janger Banyuwangi also uses Indonesian, although the use of the Indonesian language is not dominant, only limited to the opening part by the host, and sometimes at the closing. Code switching and code mixing occur. The following is an excerpt from the opening of the performance presented by the host of Janger Karisma Dewata when performing Madune Tawon Klanceng Putih. No changes whatsoever, but I put brackets and italics to indicate redundant words or phrases which, by Indonesian rules, can be omitted.

\section{Pembawa Acara}

Para penonton serta para hadirin yang berbahagia, itulah tadi [sebagai] maskot [dari] keluarga seni Janger Karisma Dewata [yang datangnya langsung] dari dusun Curah Pacul, Curah Krakal, Tambakrejo, Muncar, Banyuwangi. Seni Janger Karisma Dewata [yang] dipimpin oleh Bapak Kawit, pembina Bapak Drs. Sutaji, M.Pd. Pertama-tama kami sampaikan selamat malam juga selamat berjumpa kembali bersama pagelaran [seni] akbar seni Janger Karisma Dewata yang malam hari ini bergelora di [kota Anda yaitu daerah] Tugurejo [dan sekitarnya]. Semoga pada malam hari ini Anda bisa berhibur, bergembiraria bersama pagelaran seni Janger Karisma Dewata. [Pertama-tama] kami sampaikan [banyak] terimakasih kepada tuan rumah yaitu Ibu Ngatijem sekeluarga yang [mana] pada malam hari ini telah memberi kesempatan dan kepercayaan [yang diberikan langsung] kepada keluarga besar seni Janger Karisma Dewata [pada malam hari ini]. Tak lupa kami sampaikan pada para penonton juga para hadirin yang berbahagia, juga pada para undangan 
[yang hadir pada malam hari ini]....

(Madune Tawon Lanceng Putih, Pembukaan)

The above introduction delivered by the host uses Indonesian language with a grammar far from precise. Nevertheless the host delivered it in an ups and downs tone and rhythm, full of confidence, just like a professional performer. The audience enjoyed it, was not bothered by the grammar of the host. The use of Indonesian language at the opening of this show is not without intent. According to Sutaji, group manager Janger Karisma Dewata, the use of Indonesian language is intended to create a formal, modern, educated, and authoritative effect. Besides, according to him, the sentences at the opening have nothing to do with the content of the story, but as an introduction.

In a scene, code mixing in the form of Indonesian language vocabulary insertion is sometimes used in order to break the ice. This should not happen in a comedy act, but in a scene that should be a serious one. In Madune Tawon Lanceng Putih, when King Harjaya asked about his daughters, Kanthil Abang and Kanthil Putih responded as usual. But Kanthil Ijo, the third child, answered differently.

Raja Harjaya

Anakku, nduk, Kanthil Ijo.

Kanthil Ijo

Ada apa, Rama.

Raja Harjaya

(Terkejut, berdiri) Lho ... lho ...

Patih

Lha kok ada apa piye to, nduk?

Kanthil Ijo

Rama, apa ada.

Raja Harjaya

Karepmu ada apa iki mau, piye?

Kanthil Ijo

Panjenengan iki ora ngerti bahasa

Indonesia to, Rama?

Raja Harjaya

(Mendekati Patih, berbisik) Wah, wah, iki kemajuan ...

\section{King Harjaya}

My daughter, Kanthil Ijo.

\section{Kanthil Ijo}

What's the matter, dad.

\section{King Harjaya}

(Surprised, standing up) Oh ... oh...

\section{Patih}

What's that, dear?

\section{Kanthil Ijo}

Daddy, what's the matter?

\section{King Harjaya}

What do you mean?

\section{Kanthil Ijo}

You do not understand Indonesian, Dad?

\section{King Harjaya}

(Approaching Patih, whispering)

Well, this is a progress ...

(Madune Tawon Lanceng Putih,

Babak 1)

Bahasa Indonesia is also sometimes inserted in the comedians' dialog. More often found in this sort of code mixing is just a word or phrase, rarely in the form of long complete sentences. Below is an example cited from the dialogue between Penyet and Mentik, the comedians. 
Penyet

Arane mumpung ketemu kanca, ya tukar pikiran.

Mentik

Ya lung ayo disigar ndase ...

\section{Penyet}

(Menjitak kepala Mentik) Alah goblog!

Tukar pikiran mosok utek ira dideleh

kene, tukeran gedigu?

Mentik

Marine klendi?

Penyet

Paran iku istilahe ... gesekan.

(Senapati Majapahit, Babak 2)

\section{Penyet}

Bawa apa itu?

\section{Mentik}

Nggawa beras.

\section{Penyet}

Beras? Dhuna kabeh.

(Senapati Majapahit, Babak 2)

\section{Penyet}

When we meet a friend, we have to discuss.

\section{Mentik}

Yes let's split your head ...

\section{Penyet}

What a fool! We have to discuss, or exchange our head?

\section{Mentik}

What do you think?

\section{Penyet}

What is the term ... friction.

\section{Penyet}

What do you bring?

\section{Mentik}

I bring rice.

\section{Penyet}

Rice? Put here.

Tukar pikiran (exchange ideas) and gesekan (friction) are Indonesian vocabulary, to replace the term rembugan (discussion). Similarly, "Bawa apa itu?" (What do you bring?) is an Indonesian sentence. The use of this kind of Indonesian vocabulary is only possible on comedy acts, not in other acts. If in other acts other than comedy there appear Indonesian vocabulary, it can be ascertained that it was a deliberate act by an actor in order to obtain a funny effect.

\subsection{Diction}

Diction, or word choice, includes the meaning of which words should be used to reach an idea, how to form the correct grouping of words or using phrases, and which style is best used in a situation (Keraf, 2002; Calahan, 2016). In this sense there is a necessity for a speaker to be able to distinguish carefully the nuances of the word, so that the message he wishes to convey becomes clearer and more easily understood, avoiding the complexities of confusing notions and causing misunderstanding.

According to English Oxford Living Dictionaries (Oxford University Press, 2018), diction means 1) The choice and use of words and phrases in speech or writing; 2) The style of enunciation in speaking or singing. 
The functions of diction are, among other things, to make the readers or listeners understand correctly and not misunderstand what the speaker or the author is saying, achieve effective communication targets, symbolize ideas expressed verbally, form the right expression of ideas (very official, official, unofficial) so as to please the listener or reader.

The first meaning of diction refers to the choice of words and expression styles by the author or speaker. The second meaning of diction refers to the ability to explain so that each word can be heard and understood as intended by the author or speaker. This second meaning is more intended to pronunciation and intonation than the choice of words and style, or the ability to distinguish precisely the nuances of meaning from the idea to be conveyed, as well as the ability to find a form that is appropriate to the situation and sense of value owned by the audience.

There are three kinds of diction in Janger performance based on the used of word choice: standard diction, archaic diction, and absorption diction.

\subsubsection{Standard Dictionary}

Javanese language used in Janger performance is "standard Javanese language for traditional performance on the stage." This standard reflects the quality of Javanese as is commonly used in traditional Javanese perform art, such as Wayang Kulit, Wayang Wong, and Ketoprak. The standard also indicates the type of diction or vocabulary used, ie, "original" diction which is not the absorption of European languages vocabulary, for example: strategy, politics, engineering, economics, automobile, etc., that do not cause problems if they are used in everyday conversation of Javanese people.

Standard diction that is relatively "pure", does not cause language problems when it is used in traditional theater performances such as Janger. Here is an example.

\section{Wilabrata}

Selo Tunda, nalika semana sira sun utus supaya nimbali gembong-gembong desa.

Kepiye?

\section{Jagakersa}

Menika sampun kula cepak-cepakaken.

Dinten menika badhe sowan ngarsa Jengandika.

\section{Wilabrata}

Saiki pisan? Ngranti yen kaya ngono.

\section{Jagakersa}

Dipun rantos.

\section{(Prabu Tawangalun, Babak 1)}

\section{Wilabrata}

Selo Tunda, I told you to meet the village leaders. How is that?

\author{
Jagakersa \\ I've done all of them. Today they \\ are going to meet you, Sir.
}

\section{Wilabrata}

Now? Then we'll wait.

\section{Jagakersa}

Let's wait.

The above quotation shows the use of ngoko and krama standardized diction for Janger performance, as is commonly used in other traditional Javanese theater performances. If there is no special consideration, this kind of diction should be used throughout the performance, no absorption words from English, Dutch, or any other European languages. Nor should any words be taken from Indonesian vocabulary. 
The use of standardized diction in Janger performance makes it easy for viewers to enjoy the dialogue in the performance, and thus to follow the story. In Banyuwangi, the majority of Janger fans can communicate in Javanese even though some of them are not Javanese.

\subsubsection{Archaic Diction}

In Janger performance, diction is not just a matter of vocabulary mastery and disclosure style, but also something relates to the ability of utilizing the vocabulary in order to create dramatic atmosphere while achieving artistic value.

When performing his role on the stage, an actor must not only understand the essence of the problem he is about to utter, but must also understand the diction he uses. Diction is not just a matter of choosing the word used to express an idea or telling an event, but it also involves the issue of the style of language as well as the peculiarities of expressing the phrases. The language style is part of diction which relates to the way of individual inducement to create certain characteristics, and thus has a high artistic value. Therefore, in addition to using regular vocabulary, in which the audience will immediately know its meaning because it is used in everyday communication, a Janger actor needs to support himself by using an archaic Javanese vocabulary. The definition of archaic described in English Oxford Living Dictionaries (Oxford University Press, 2018) is something related to the past or ancient and obsolete.

Quite often in Janger performance the actors use sentences with archaic vocabulary, or ancient words that are not easily understood meaning, or even not understood at all by viewers because they have never been used in everyday communication. It was intended as an attempt to create a certain atmosphere. The audience already knows that the character is angry, joyful, lovesick, and so forth, so the contents of the sentence that is spoken or the contents of the song sung is considered insignificant to be known. However, the sentence or the song should be spoken or sung in order to create a more "concentrated" atmosphere. Examples of archaic vocabulary in Janger performance are as follows.

\section{Wilataruna}

Kawiyos raras nggen dhawuh ingkang

kawedhar kalawau, kula sanget

nayogyani, Rama. ...

(Prabu Tawangalun, Babak 1)

\section{Wilobroto}

Sedaya kula akeni. Kula boten badhe andhemit tetebihing toya, pancen kula ingkang ndadha. Kula seger aminum kakampuh jidhu. ...

(Prabu Tawangalun, Babak 4)

\section{Wilataruna}

It look brilliant all the words that have been spoken earlier, I am very agree, Father.

\section{Wilobroto}

All I admit. I will not deny it, I did it. If I were to drink poison, I would not be afraid.

Some of the vocabulary in the above quotations are words that are no longer used, or at least very rarely found in everyday conversations. The words kawiyos, raras, kawedhar, and nayogyani refer to high-level languages commonly used in the literary writing or performing art such as Ketoprak or Wayang Kulit Purwa. In the next quotation, the phrase andhemit tetebihing toya is a metaphor, which means behaving like a ghost runs away from 
water, afraid of splashing water, aka avoiding responsibility. Seger aminum kakampuh jedhu is also an allegory, which means "to keep fit while drinking poison" (jedhu, Saskerta, deadly poison), aka will not retreat or avoid responsibility. Though what Wilobroto had done was a disgraceful act, this statement was an attitude of knight.

The quotation above shows that the diction used in Janger performance not only contains the vocabulary of the Javanese language picked up from everyday conversation, but is sprinkled with many archaic vocabulary that is not easily understood by most audiences. However, it does not diminish the audience's understanding of the storyline, because in fact they already know the content, or can estimate it, so that their concern is the "form" of the performance embodied into the beauty of language, motion, and tone.

\subsubsection{Absorption Diction}

Language and society are two entities that cannot be separated (Romaine, 2000; Wardhaugh, 2001). A language develops in accordance with the dynamics of its user, so that everything that happens in a society has a systematic and direct implication to the language it uses. When a society develops, interacts with other societies, then its language can certainly participate in developing and on a certain scale influenced by other languages. That is, a society will absorb other cultural elements of society, including the language.

From time to time Banyuwangi people, including Janger artists, are dynamically responding to the changes and developments of the natural environment and its socio-cultural environment. This is reflected in the realm of language, namely the emergence of efforts to absorb some vocabulary from other languages. Javaesen and Using languages used in Janger performance are not able to perfectly free themselves from the influence of other languages. It also shows that communication system in Janger performance is dynamic and loose. In everyday life, besides using Javanese and Using languages, Banyuwangi people also use Madurese, Indonesian, and, in certain degree, foreign languages especially English and Arabic.

Indonesian vocabulary is the most widely absorbed in Janger performance. This is understandable because Banyuwangi people are integral part of Indonesian society, and they formally use Indonesian language to communicate. A number of Indonesian vocabulary are absorbed directly without any change in form and meaning.

\section{Minak Jingga}

Isuk mikir, Yun, sore nggonku mikir.

Ning sing tak pikir lha kok ora krasa ya, Yun?

\section{Dayun}

Oh, ngaten to Lurahe? Ngaten, Lurahe.

Tumbas bakso mangkoke pecah,

Lurahe.

\section{Minak Jingga}

Lha piye tegese kuwi, Yun?

(Senapati Majapahit, Babak 1)

\section{Minak Jingga}

Morning thought, Yun, I'm thinking of her every time. Does she know it, Yun?

\section{Dayun}

Oh I see, Lurahe. Purchased meatball but the bowl is broken, Lurahe.

\section{Minak Jingga}

What does it mean, Yun? 
In the above quotation, the word bakso (meatball) is not a standard word in Javanese. This word had not been known by Javanese society in the pas. Other uptake vocabulary, including from Indonesian language, is used to gain clarity of meaning and to avoid different interpretations of what is meant by the author / speaker. The consequence of it is the use of other language vocabulary. The use of the phrase banjir darah (blood flood) above is an example. In addition, as mentioned earlier, the diction used in Janger performance is a standardized diction, ie, a "native" diction that is not an uptake of European languages that does not pose a problem if used in daily Javanese conversations. If such a diction is used in Janger performance, it can certainly have a particular interest, for example to cause a funny or informal effect, in addition to the fact that Javanese language is unable to explain certain social phenomena that exist in today's society. The comedians get the greatest freedom to take advantage of this linguistic leniency.

\subsection{Code Switching and Code Mixing}

The supporters of Janger performance are a society with various cultural backgrounds. Therefore Janger performances, although using Javanese as the primary language, are unlikely to avoid completely other languages influence. Intensive language contacts between two or more languages in bilingual / multilingual daily communication situations such as in Banyuwangi result in the phenomenon of language commonly called code switching and code mixing. In addition, Janger performance presupposes the presence of social stratification through the use of language, both Javanese and Using languages. This is what causes code switching or code mixing. Moreover, in a multilingual society it is very difficult for a speaker to use one language completely. So are Janger actors, although obliged to conduct their dialogue in Javanese, but there is always another language vocabulary that is used in the dialogue they convey.

Code switching and code mixing have something in common, that these two linguistic events are common in multilingual societies. While the difference, code switching occurs when each language used still has its autonomy, done consciously and deliberately for certain reasons. A linguistic event is called a code mixing when the main code or basic code used still has its function and autonomy, while the other code involved in the use of the language is just an insertion, with no functionality and autonomy as a code. In other words, other language elements are only inserted in the main code or base code. According to Kridalaksana (2008), if in a conversation there is a transition from one clause of a language to another language clause then the event is called as code switching. But if in a conversation the clause or phrase used consists of mixed clause or phrases (hybrid cluases/hybrid phrases) and each clause or phrase does not support its own function anymore, then it is called a code mixing.

\subsubsection{Code Switching}

Code switching is a transition from a code to another code in a speech event. For example, a speaker applies Using and then switch to applay Javanese, or vice versa. Code switching is one aspect of language dependency in multilingual society. In the event of code switching, each language tends to support each function according to its context. Nababan (1984) states that the concept of code switching includes also the occurrence at which a speaker moves from one variety of languages to the other. For example, the formal variety to casual variety, from krama inggil (high level, Javanese) to ngoko (low level), and so forth. 
According to Holmes (2001), code switching may reflect the dimensions of social distance, status relationships, or the level of formality of the interaction of speakers.

Suwito (1985) divides code switching into two types, namely: 1) external code switching, if there is a transfer of language, such as from Using switch to Javanese or vice versa, 2) internal code switching, from Javanese krama switch to ngoko.

\subsubsection{From Using to Javanese}

In Janger performance, based on certain considerations, the comedians are allowed to apply a language other than Javanese, such as Using or Madurese, or a combination of Javanese with other languages. Here is one example of code switching from Using to Javanese.

\section{Penyet}

Kene, kene ... Ya kudune awake dewek iki kudu pinter ndeleng situasi. Ya nek ngadepi hang gedigu iku ... ya muga-muga aja sampek. Tapi upama ketotol, ketemu tenanan, ya carane kudu dirembug hang apik.

\section{Mentik}

Saiki gedigi, Lik ... awake dewek iki ngemong Ndara ... hang ati-ati, hang sabar.

\section{(Damarwulan datang)}

\section{Penyet}

Lha iya, awake dewek iki arane ...

\section{Mentik}

Abdi.

\section{Penyet}

Ho-oh. Jongos. Ngemong mulai ndesa sampek panggonan kene. Cita-citane kepingin urip enak, e tibane nong kene ya ... byek, dirasani ...

\section{Penyet}

Come here, please ... we should have to know the situation. If we are facing that problem ... well, hopefully we are fine. But if we mee him, we must talk it first.

\section{Mentik}

By the way, Lik ... we are nurturing Ndara ... we must cautious, must be patient.

(Damarwulan is coming)

\section{Penyet}

Yes, indeed ... we are ...

\section{Mentik \\ Helper.}

\section{Penyet}

Yes. Helper. Taking care from the village to this place. He wants to live well, but it here... well, it is discussed ...

In the quotation above, first Mentik and Penyet chat in Using, however, when Damarwulan came they both changed their chatting into Javanese. This code switching indicates a change from a relaxed, informal situation to a formal one.

\subsubsection{Code Mixing}

Nababan (1984) says that code mixing is a state of speech in which people mix two (or more) languages or different languages in a speech act. In code mixing a speaker slips the elements of another language while using a certain language. Code mixing occurs when a speaker uses a language predominantly supports a speech inserted with other language elements. This is usually related to the characteristics of the speakers, such as the background 
of the social, education level, and religious sense. Usually the prominent feature is casual or informal situation. However, this can also happen because of the lack of language skills, or the expression in the language has no equivalent synonym, so there is a compulsion in using another language vocabulary, although it only supports one of many functions. In this code mixing the speaker consciously or deliberately uses other language elements while speaking.

In its actual form, the code mixing can be a word, phrase, or clause insertion, and also phrase or idiom insertion as shown in the quotation below.

\section{Mentik}

Marine klendi?

Penyet

Paran iku istilahe ... gesekan.

(Senapati Majapahit, Babak 2)

\section{Penyet}

Maksud isun takon, merk kendaraan kan macem-macem.

\section{Mentik}

Iya, iku hang akeh penumpange, taxi ... taxi.

(Senapati Majapahit, Babak 2)

\section{Penyet}

Stop! Sopir, turun! Bawa apa itu?

\section{Mentik}

(Turun dari mobil) Paran?

(Senapati Majapahit, Babak 2)

\section{Mentik}

Waspada neng paran.

\section{Penyet}

Kudu siap jiwa dan raga. Mental dan mentol. Maksude iki njaba-njere wis pas. Soale neng ndalan iki resikone ya macemmacem, ya kudu ngerti rambu-rambu.

(Senapati Majapahit, Babak 2)

\section{Mentik}

So what?

\section{Penyet}

What is the term ... friction.

\section{Penyet}

I mean I'm asking, there are a lot of vehicle brand.

\section{Mentik}

Yeah, that's it, with lot of passengers, taxi ... taxi.

\section{Penyet}

Stop! Driver, get off! What do you bring?

\section{Mentik}

(Get off the car) What?

\section{Mentik}

Be wary of what.

\section{Penyet}

Must be ready, soul and body. Mentally and menthol. I'm already fit. There are so many risk, we must understand the signs.

The above quotations are taken from conversations by the comedians when they are applying Using language. For certain purposes, vocabulary, phrases, or idioms originating from Indonesian language are often applied. In the first quotation, there is an absorption of the word gesekan (friction), in the second quotation there is a phrase merk kendaraan (vehicle brand), on the third quotation Penyet says "Stop! Sopir, turun! Bawa apa itu?" (Stop! Driver, get off! What do you bring?), and on the fourth quotation, Penyet says "siap jiwa dan raga" 
(fully prepared, soul and body). In Janger performance, this large numbers of Indonesian vocabulary absorption is only common in comedy acts. The comedians, in order to produce maximum jokes, get the greatest freedom of language. If necessary the comedians do not just absorb the elements of other languages, but may use other languages in their jokes.

In the other acts, besides the comedy act, the uptake of other languages is rare and hard to find. An example of the uptake of the Indonesian vocabulary in the Javanese scene is as shown in the following quotation.

\section{Tawangalun}

Cukup, adi Wilabrata! Tinimbang negara kisruh, akeh pangorbanan kang dumawa ana ing praja Kedawung, praja bakal sun pasrahke.

\section{Wilabrata}

Dipun pasrahaken kula?

\section{Tawangalun}

Iya.

\section{Wilabrata}

Mapan menika ingkang kula rantos.

Menawi boten diparingaken, banjir darah.

(Prabu Tawangalun, Babak 5)

\section{Tawangalun}

Enough, my brother Wilabrata!

Rather than the chaotic state, many sacrifices are occurring in this country, I will deliver this country to you.

\section{Wilabrata}

You'll deliver it to me?

\section{Tawangalun}

Yes.

\section{Wilabrata}

That's what I'm waiting for. If you don't deliver it to me, there will be a blood flood.

In the above quotation, the phrase banjir darah (blood flood) is a typical Indonesian expression, used by Wilobroto to emphasize that what he is saying is very important. Actually the phrase banjir darah can still be translated into banjir getih, but it was not done by the actor. Probably because banjir darah has become a common term and well known by the audience, including the Javanese community, as well as to emphasize the existence of 'critical' situations in the ongoing scene. In this scene Wilobroto is indeed hostile and threatening Tawangalun, his own brother (a rising action part of the play).

\section{Conclusion}

Janger is a typical Banyuwangi folk art that can be considered as an example of diversity in unity because the creation process does not rely on one kind of art from a particular ethnicity, but on various types of art from various ethnics which are then re-created so that it is unique. Although the three major ethnic groups in Banyuwangi have different languages, namely Using, Javanese, and Madurese, they can jointly become Janger supporters because they share the same common vision. Using, Javanese, and Madurese people are Muslims, and Islam has colored their culture for centuries. Therefore, based on the characteristics it possesses, Janger cannot be specifically referred to as Using, Javanese, or Madurese performing art. Using performing art in Banyuwangi shows the characteristics of Using, Javanese performing art in Banyuwangi remains the same as Javanese performing arts 
in other areas, and so Madurese performing art in Banyuwangi is no different from Madurese performing art in Madura island. Janger is Banyuwangi traditional performing art.

Janger embraces cultural diversity, it becomes a house of equivalent plurality, so it can be comfortably occupied by its inhabitants. It is in harmonious equality that cultural identity is laid, a common foundation in constructing a dream house called "the future." Through Janger performing art, Banyuwangi people create a new world where plurality is no longer a problem. Janger tries to tame the leaps of modernity in many areas that occur outside of the stage in order to be a "village style" in accordance with Janger's. Thus, Janger position in the cultural livelihood of the society (rites of passages) is to control the change of status that occurs to remain in tradition corridor, in addition to being integrative.

Janger performing art has proved that, amidst the power of literacy over the culture of the modern world, orality still persists and flourishes in its own way. This shows that orality still considered to have advantages. The primary advantage is that, among other things, it can record and store "millions of megabytes of data" of knowledge and traditional values in the memories of its people; it does not only make them living memories, but also living traditions that can break through the passage of time, from one generation to the next. However, in terms of inheritance, it can be said that they way of Janger inheritance mechanism is "without mechanism." Therefore it is necessary to think about the systematic and planned Janger inheritance process in order to obtain the best human resources to sustain Janger artistic survival in the future.

Through Janger we can learn how a group of plurality-based people has jointly developed their liquid cultural identity, which may in some ways be a model for the development of national cultural politics.

\section{Daftar Pustaka}

Arps, Bernard.2010. "Terwujudnya Bahasa Using di Banyuwangi dan Peranan Media Elektronik di Dalamnya (Selayang Pandang, 1970-2009)" dalam Mikihiro Moriyama dan Manneke Budiman (eds.). Geliat Bahasa Selaras Zaman: Perubahan BahasaBahasa di Indonesia Pasca-Orde Baru. Tokyo: Research Institute for Languages and Cultures of Asia and Africa (ILCAA) Tokyo University of Foreign Studies.

Calahan, Joel. 2016. "What Is The Language Of Poetry? Diction, Dialect, And Speech In Nineteenth-Century Lyric". A Dissertation. Chicago, Illinois: The University Of Chicago.

Faruk dan Aprinus Salam. 2003. Hanya Inul. Yogyakarta: Pustaka Marwa.

Holmes, Janet. 2001. An introduction to sociolinguistics. Edinburgh: Person Education Limited.

Hymes, D. 1973. Foundations in Sociolinguistics: An Ethnographic Approach. Philadelphia: University of Pennsylvania Press.

Keraf, Gorys. 2002. Diksi dan Gaya Bahasa. Jakarta: Gramedia Pustaka Utama.

Lyotard, Jean. ThePostmodern Condition: A Report on Knowledge. Oxford: Manchester University press.

Macedo, Donaldo, at al. 2003. The Hegemony of English. Boulder: Paradigm Publishers. 
Mahootian, S. 2006. “Code Switching and Mixing”. In K. Brown (Ed.), Encyclopedia of Language \& Linguistics. Oxford: Elsevier.

Nababan, P.W.J. 1986. Sosiolinguistik: suatu pengantar. Jakarta: Gramedia.

Oxford University Press. 2018. English Oxford Living Dictionaries. https://en.oxforddictionaries.com/

Romaine, Suzanne 2000. Language in society. An introduction to sociolinguistics. 2nd edition. Oxford: University Press.

Spolsky, Bernard. 1998. Sociolinguistics. Oxford: Oxford University Press.

Sutarto. 1997. Legenda Kasada dan Karo Orang Tengger Lumajang. Disertasi S3. Jakarta: Universitas Indonesia.

Suwito. 1985. Sosiolinguistik: Pengantar Awal. Surakarta: Henary Offset.

Wardhaugh, Ronald 2001. An introduction to sociolinguistics. 4th edition. Oxford: Blackwell.

Yuliana, Nana, dkk. 2015. "Code Mixing and Code Switching Of Indonesian Celebrities: A Comparative Study”. Jurnal LINGUA CULTURA Vol.9 No.1 May 2015. 